\title{
Investigation of Quenched No. 2 Blast Furnace at Kokura Works"
}

\author{
By Kantaro SASAKI, ,* Fumitada NAKATANI, ${ }^{* * *}$ Michiharu HATANO, ** \\ Masao WATANABE, ${ }^{\dagger}$ Teruhisa SHIMODA, ,* Katsuhiro YOKOTANI,*** \\ Takao ITO ${ }^{\dagger \dagger}$ and Takashi YOKOI+†
}

\section{Synopsis}

When Kokura No. 2 B.F. was blown out on September 25, 1974, the furnace was quenched with water and the inner part of the blast furnace was investigated for the following items.

1) The distribution of burden materials, the pattern of melting zone and the shape of the raceway in the furnace

2) The change in the properties of coke and sinter in the furnace

3) The relationship between the operational conditions and some phenomena in the furnace

\section{Introduction}

For the operation of a blast furnace it is very important to know the situation of descending, the distribution and the process of reactions of burden materials in the furnace, which are the major topics for the blast furnace operations.

Informations concerning the raceway which are considered to have a great influence on the control of the gas-flow in the furnace, the shape and size of the raceway, the behavior of coke, and the influence of the properties of coke on it, are very useful for the blast furnace operators.

However, the measurements inside the furnace during operation are very difficult due to high temperature and high pressure. The only possible method to know the situation inside the furnace is the coreboring and sampling of coke in front of the tuyere during blowing out and the observation through a sight hole in the tuyere during operation.

Hence, some investigations have recently been made at several companies ${ }^{1-4}$ for their blast furnaces blown out and quenched after normal operation in order to know the distributions of burden materials inside the furnaces and the changes in their properties.

Aims of the investigation inside the furnace are:

1) to clarify the complex phenomena taken place in the furnace by knowing the distribution of burden materials in the furnace and the changes of their properties

2) to realize the actual states of melting zone and raceway which decide the blast furnace condition

3) to revise the specification of raw material to be charged by analyzing the process of the changes in their properties.

Thus it is considered to be effective means to obtain valuable informations for the operation of a blast furnace.

For the first time the authors investigated the in- side of Kokura No. 2 blast furnace blown out and quenched with water on September 25, 1974.

The distribution of burden materials in the furnace, the changes in their properties and some discussions on the relationship between the operational conditions and the phenomena observed inside the furnace are reported in this paper.

\section{Method of Investigation}

After Kokura No. 2 blast furnace charged with normal materials was blown out and quenched with water, the observation of the distribution of burden materials in the furnace and the sampling of them were done by hand-digging and boring in the region below the shaft level to study the inside of the lower part of the furnace.

As shown in Fig. 1, the burden materials were sampled from 16 levels in the region between the lower part of the shaft and the tuyere level in the vertical direction, 9 places for each level and 12 places near by the raceway for each tuyere.

Table 1 shows the outlines of the blast furnace investigated.

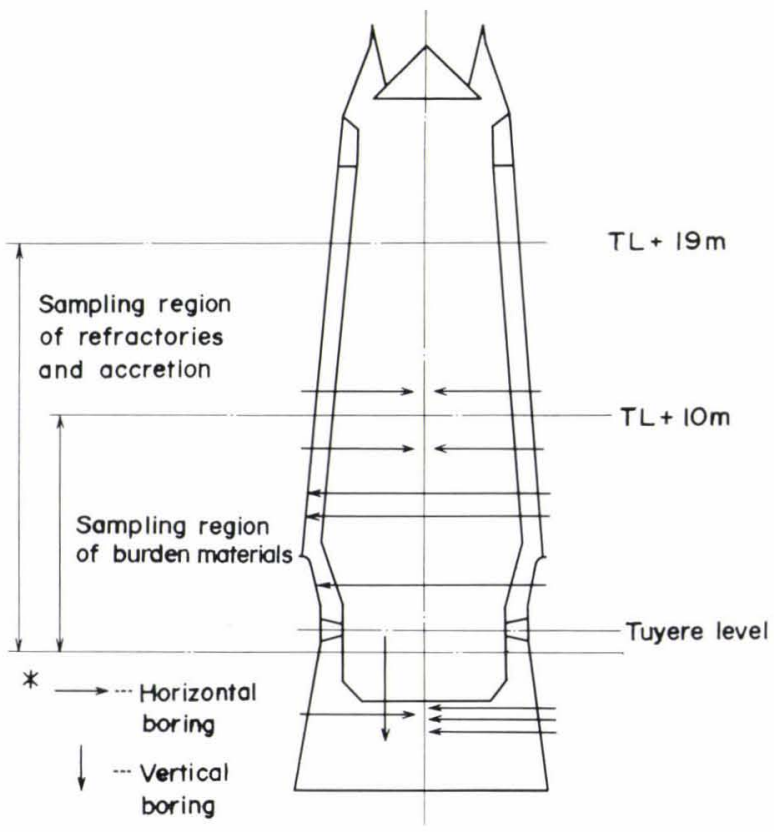

Fig. 1. The investigated region in Kokura No. 2 B.F.

* Originally published in Tetsu-to-Hagané, 62 (1976), 580, in Japanese. English version received July 7, 1976.

** Central Research Laboratories, Sumitomo Metal Industries, Ltd., Nishinagasu-hondori, Amagasaki 660.

*** Head Office, Sumitomo Metal Industries, Ltd., Higashi-ku, Osaka 541.

$\dagger \quad$ Kashima Works, Sumitomo Metal Industries, Ltd., Kashima-cho, Kashima-gun, Ibaraki 314.

† Kokura Works, Sumitomo Metal Industries, Ltd., Kokura-Kita-ku, Kitakyushu 802. 


\section{Results of the Study}

From the present study, it has been found that a stratified structure of coke and ore caused by the alternate charging of them was preserved to the lower part of the furnace and that the bed coke consisting of coke and dropped iron with an inverse $\mathrm{V}$-shape was existing in the central zone of the furnace.

\section{Distribution of Burden Materials in Furnace}

\section{Stratified Structure of Coke and Ore-layers}

The stratified structure of coke and ore-layers is preserved in the whole region at every level up to $6 \sim 7 \mathrm{~m}$ above the level of tuyere where the ore begins softening, sintering and melting in the central zone of the furnace, below which it remains only in the region between the intermediate and the peripheral zones of the furnace due to the existence of bed coke in the central zone of the furnace. In the region below the level where softening and melting start, a part of the ore-layer adjoining to the bed coke is sintered in the state similar to rock.

Although the repose angle of the coke and the orelayers is already known to be usually a little larger than $30^{\circ}$ at the top of the furnace from the result of a charging test, it was observed to be about $10^{\circ}$ at the position below the lower part of the shaft in the current investigation. It is considered that as the burden materials descend, the repose angle is reduced, because the speed of descending becomes higher at the peripheral zone of the furnace than that at the central zone owing to the consumption of coke at the raceway.

\section{Softening Zone and Bed Coke}

Softening zones are developed from the neighborhood of the bed coke towards the furnace wall with an inverse $\mathrm{V}$-shape and are distributed in the stratified

Table 1. Outlines of Kokura No. 2 B.F.

\begin{tabular}{ccccc}
$\begin{array}{c}\text { Inner } \\
\text { volume }\end{array}$ & $\begin{array}{c}\text { Hearth } \\
\text { diameter }\end{array}$ & $\begin{array}{c}\text { Top } \\
\text { pressure }\end{array}$ & $\begin{array}{c}\text { Tap } \\
\text { hole }\end{array}$ & Tuyere \\
\hline $1350 \mathrm{~m}^{3}$ & $8.4 \mathrm{~m}$ & $1.05 \mathrm{Kg} / \mathrm{cm}^{2} \mathrm{G}$ & 2 & 22
\end{tabular}

structure having a doughnut-like shape as shown by black parts in Fig. 2. Figure 3 shows an example of softening zone at level $4 \sim 5 \mathrm{~m}$ above the tuyere (the part of belly) which droops in the central zone of the furnace and rises near the wall to form a doughnutlike shape. At the bottom of the softening zone, ore is melting in the state just before dropping and thus it encroaches upon a coke-layer as shown in the vertical cross section.

The boundary between the bed coke and the softening zone is a melting zone where ore is heated, reduced and starts to melt. The melting zone may show, as reported by other investigators, an inverse $\mathrm{V}$-shape, W-shape or $\mathrm{V}$-shape according to the operational conditions. The fact that the melting zone showed an inverse $\mathrm{V}$-shape in the present investigation is considered to be due to the operational condition in which the gas flow in the central zone of the furnace

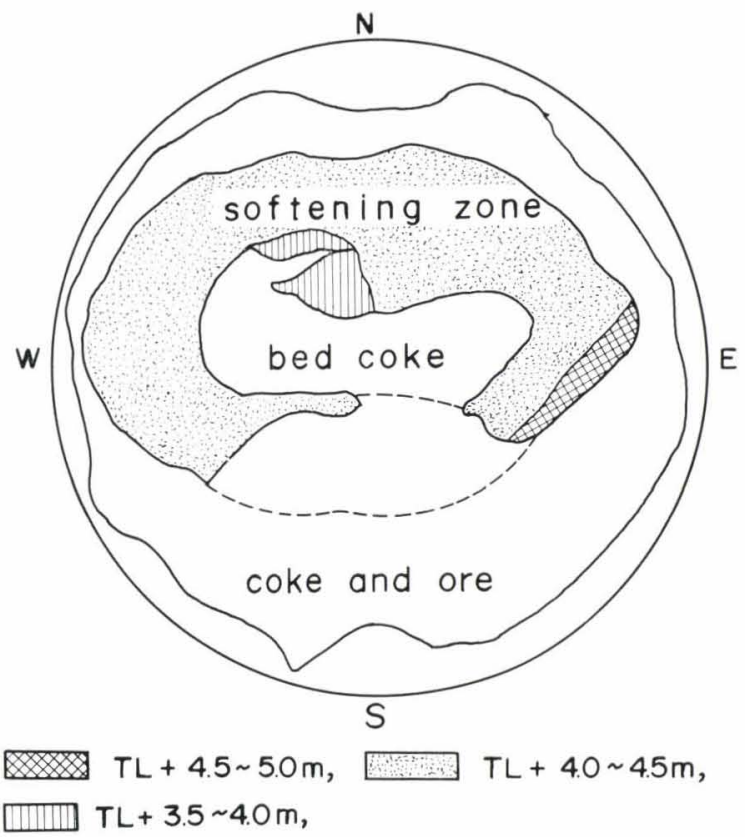

Fig. 3. Horizontal section of the softening zone at 3.5 $5.0 \mathrm{~m}$ above the tuyere level

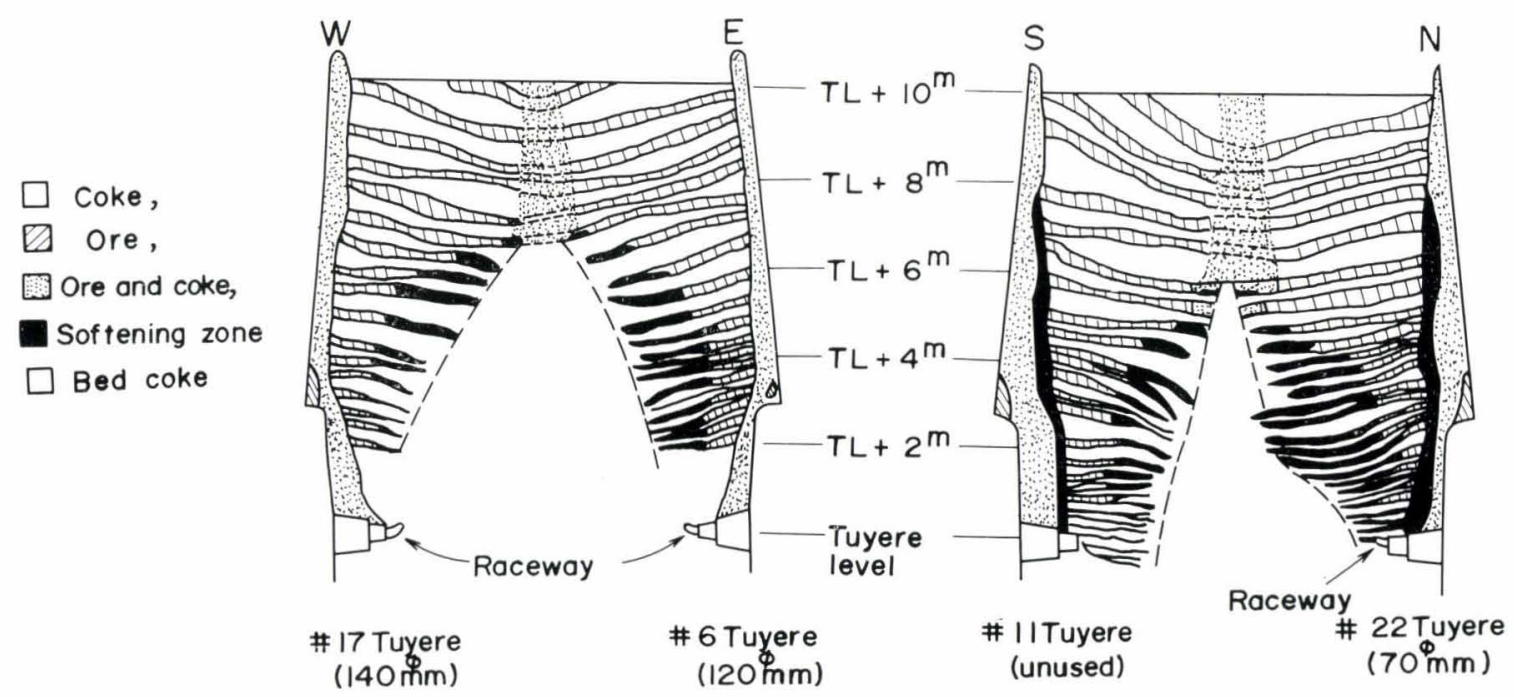

Fig. 2. Distribution of burden materials in Kokura No. 2 B.F. 
was stronger than that in the peripheral zone. The shape of the melting zone which depends strongly on the gas-flow in the furnace can transform to W-shape when the gas-flow near the wall is strengthened since the degree of inverse V-shape is decreased.

\section{State of Raceway}

The burden materials in the furnace at the tuyere level consist of coke, pig iron and slag existing among the coke particles or on their surfaces. The difference between the states of burden materials near the raceway and of the bed coke is that the former contains more pig iron and slag remained between coke particles and is more densely packed than the latter. This is probably because the softening zone near by the wall descends to just above the raceway and melts so rapidly that the molten slag remains between coke particles without obtaining sufficient fluidity to drip to the hearth. Therefore, the permeability in the vicinity of the raceway is perhaps hindered by the operational condition in which the softening zone descends to the lower part of the furnace near by the wall as in the case of this blast furnace.

The shape of the raceway at each tuyere is shown in Fig. 4. The characteristics of the shape of the raceway is that double or triple shells of raceway were confirmed as shown by broken line in the horizontal cross section in Fig. 4. The shell of the raceway is formed by the layer in which fine particles of coke and molten slag are densely adhered each other. This is considered to be the skeleton of the raceway formed in accordance with the reduced volume of blast before blowing out, which shows the depth of the race-
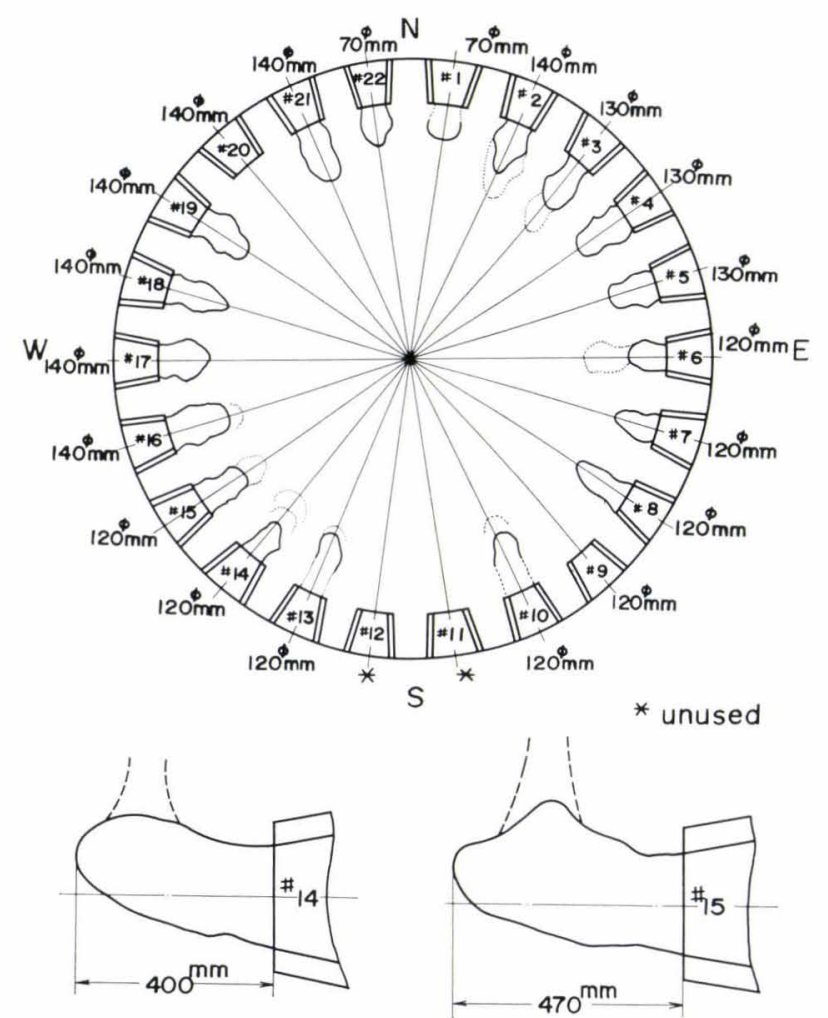

Fig. 4. Distribution of raceway at the tuyere level and the vertical section of raceway way changes in accordance with the condition of blast. As the vertical section of the raceway in Fig. 4 shows, generally a raceway is developed in the upward direction towards the center of the furnace, and a cylindrical body (shown by the broken line in the figure) in which coke is very coarsely packed is observed in the upper portion of the raceway.

Moreover, a skeleton of raceway is found in the softening zone in the north part of the furnace where the softening zone descended to the level of tuyeres.

\section{Changes in Properties of Coke in Furnace}

Coke in a blast furnace acts as an agent to preserve the permeability for gas and liquid as well as a heat source and a reducing material. From the view point of stable operation of a blast furnace, the degradation of coke size in the furnace should be avoided in order to preserve a good permeability in the furnace.

Figure 5(a) shows the distribution of coke size in the direction of furnace height. A remarkable degradation of coke size is observed in the region $2 \sim 3 \mathrm{~m}$ above the tuyere level.

This phenomenon is caused by the severe chemical and physical conditions in the lower part of the furnace and substantially, we consider, by the change in the properties of coke brought about chemically at high temperatures and pressures. This is proved by the fact that the degradation of the drum strength $\left(\mathrm{DI}_{15}^{30}\right)$, which is an indication of the macro strength of coke, becomes remarkable in the region $2 \sim 3 \mathrm{~m}$ above the tuyere as shown in Fig. 5(b).

The reaction between coke and $\mathrm{CO}_{2}$ gas is assumed to be the cause of the degradation of the macro strength in the lower part of the furnace. There is a negative correlation between the macro strength of coke and

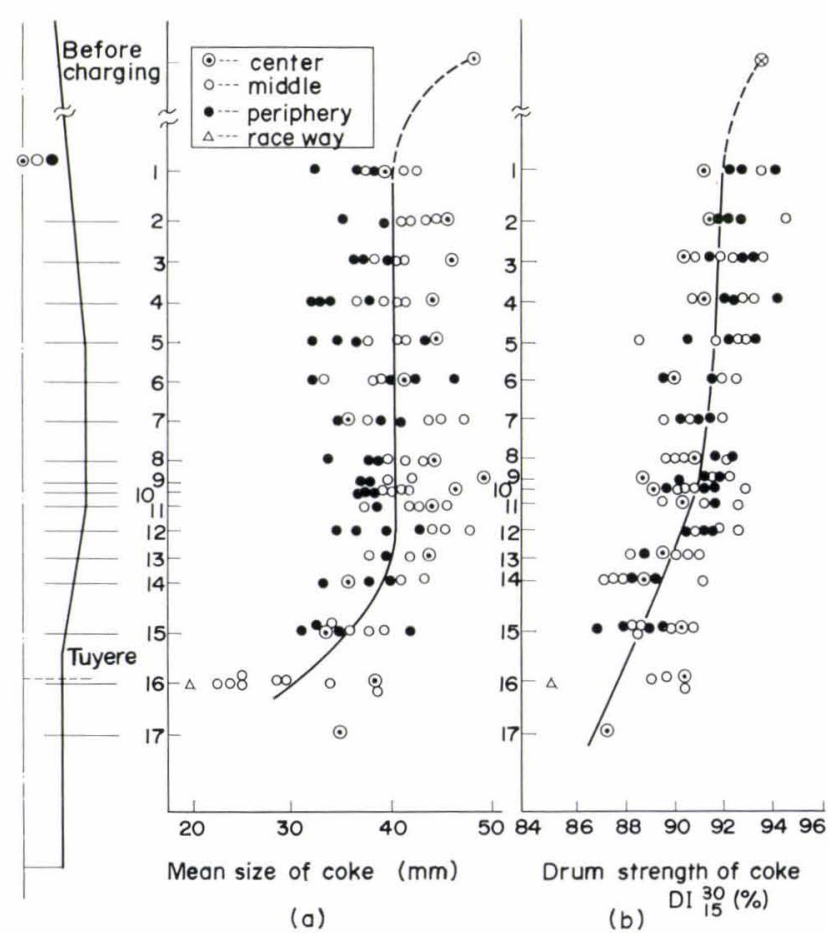

Fig. 5. Longitudinal distributions of mean size and drum strength of coke 
its reactivity which is an index to show how easily the solution loss reaction of carbon occurs, and it suggests that the degradation of the strength is caused by the increase in the reactivity. As an example, the relationship between the reactivity and the hot strength $\left(\mathrm{HSI}_{6}^{400}\right)$ is shown in Fig. 6(a).

It has been pointed out that the reactivity of coke is accelerated by the catalytic action of alkali metals and the increase of reaction surface. In this investigation as shown in Fig. 6(b), there also exists a positive correlation between the reactivity and the amount of alkalis $\left(\mathrm{K}_{2} \mathrm{O}+\mathrm{Na}_{2} \mathrm{O}\right)$ in the ash of coke, and their maximum values coincide each other in their distributions in the direction of furnace height as shown in Fig. 7, which means that coke is transformed into gaseous state by the catalytic action of alkalis. Further, it has been experimentally confirmed by using an electric furnace shown in Table 2 that the amount of coke reaction in the atmosphere of alkali $\left(\mathrm{K}_{2} \mathrm{CO}_{3}\right)$ at $950^{\circ} \mathrm{C}$ under the $\mathrm{CO}_{2}$ flow rate of $12 \mathrm{l} / \mathrm{min}$ during the reaction period of $1 \mathrm{hr}$ is twice larger than that in the case without the addition of alkali or more.

The increase of the alkali content in the ash of coke which is enriched from the content of about 3\% before charging to about 10 to $20 \%$ is considered to be due to the low boiling point of alkali ${ }^{5,6}$ by which it is easily reduced or oxidized and is accumulated by the recirculation between high temperature and low temperature zones of the furnace. Especially $\mathrm{K}_{2} \mathrm{O}$ is more conspicuously accumulated in the furnace than $\mathrm{Na}_{2} \mathrm{O}$ as shown in Table 3 .

Sodium is found to be segregated around pores and

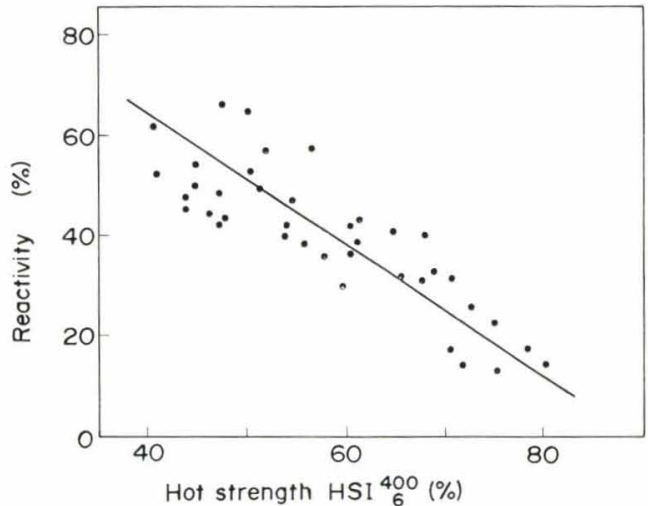

(a)

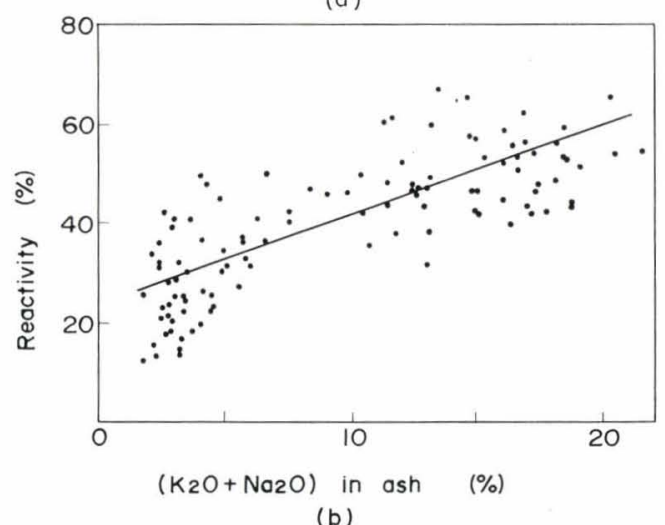

Fig. 6. Relationships between reactivity, hot strength and content of alkali oxides in coke ash potassium is found to be scattered in the wall of pores according to the EPMA examination of alkalis condensed in coke as shown in Photo. 1.

It is assumed that the wall thickness of pores in coke decreases as the gasification is accelerated by the catalytic action of alkali condensed in the high temperature zone according to the mechanism described above, which causes an increase in the number of pores and a decrease in the macro strength. This assumption is supported by the negative correlation between the porosity and the macro strength as shown in Fig. 8.

The micro strength of coke (MSI) which is an index of the abrasion resistance increases at the lower part of the furnace, being probably not a cause of the degradation of coke size in the furnace.

From the discussion described above, it can be con-

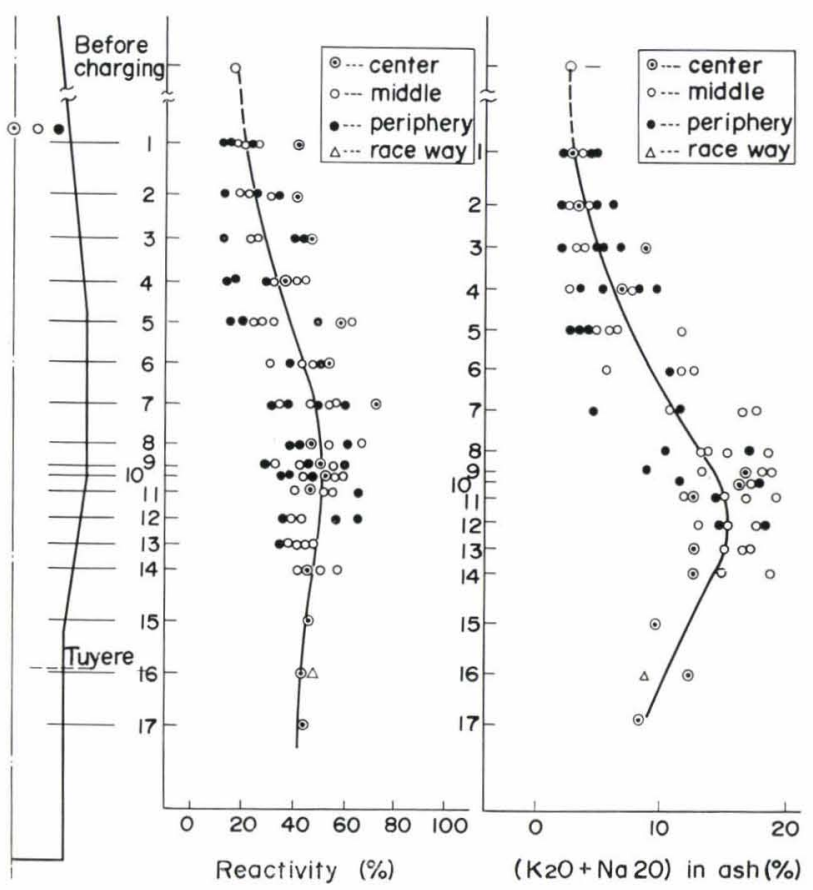

Fig. 7. Longitudinal distributions of reactivity and content of alkali oxides in coke ash

Table 2. Comparison of the reactivities of coke with and without alkali

\begin{tabular}{l|ccc|c}
\hline \multirow{2}{*}{ Alkali } & \multicolumn{2}{|c|}{ Change of coke weight } & Reaction rate \\
& $\begin{array}{c}W_{0} \\
\text { (before } \\
\text { reaction) } \\
(\mathrm{g})\end{array}$ & $\begin{array}{c}W_{1} \\
\text { (after } \\
\text { reaction) } \\
(\mathrm{g})\end{array}$ & $W_{0}-W_{1}$ & $\frac{W_{0}-W_{1}}{W_{0}} \times 100$ \\
\hline Without alkali & 1493.0 & 1420.5 & 72.5 & $(\%)$ \\
\hline With alkali & 1515.5 & 1355.5 & 160.0 & 10.6
\end{tabular}

Table 3. Alkali content in the coke ash of blast furnace

\begin{tabular}{l|ccc}
\hline & $\begin{array}{c}\text { Before } \\
\text { charging }\end{array}$ & $\begin{array}{c}\text { At T.L. } \\
+7.0 \mathrm{~m} \\
\text { level }\end{array}$ & $\begin{array}{c}\text { At T.L. } \\
+3.5 \mathrm{~m} \\
\text { level }\end{array}$ \\
\hline $\mathrm{K}_{2} \mathrm{O}$ in the coke ash (\%) & 1.9 & 3.2 & 11.6 \\
$\mathrm{Na}_{2} \mathrm{O}$ in the coke ash (\%) & 1.2 & 2.0 & 3.5
\end{tabular}




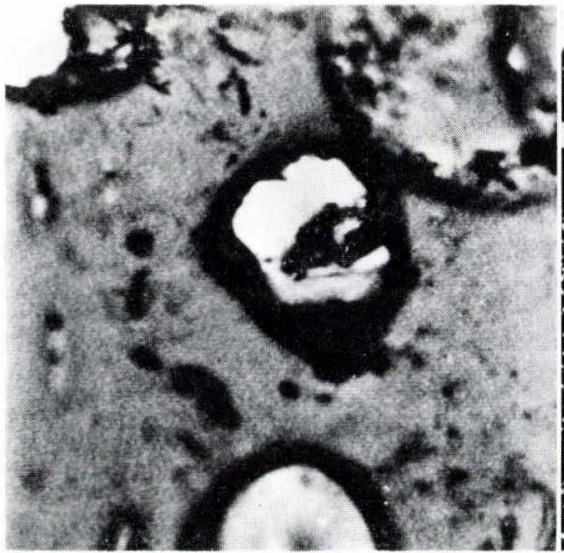

(a) Micro photograph

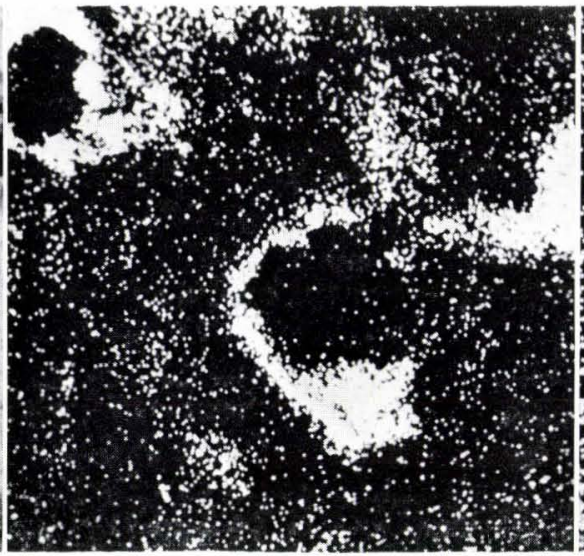

(b) EPMA photograph: $\mathrm{Na}$

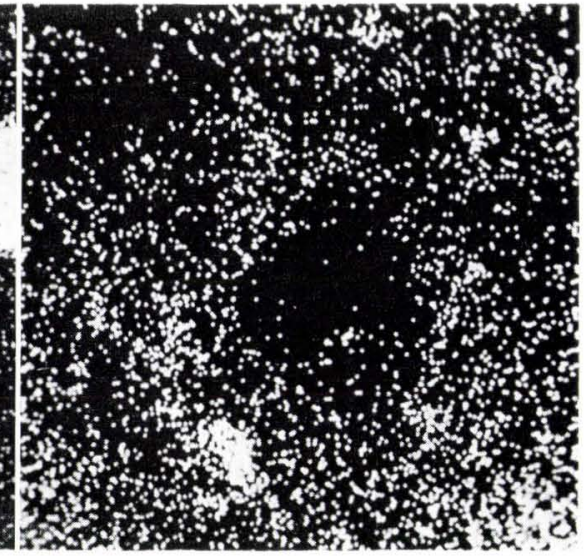

(c) EPMA photograph: K

Photo. 1. Concentrated alkalis around pores detected by EPMA (At T.L. $+4.5 \mathrm{~m}$ level $)(\times 400)(\times 2 / 3)$

cluded that the degradation of coke size at the lower part of the furnace is caused by the decrease in the macro strength due to the gasification of coke by the catalytic action of alkalis as well as by the increase in the severeness of physical conditions, especially by the fluidization and collision by the energy of blast in and near the raceway.

\section{Change in Properties of Sinter in Furnace}

\section{Re-oxidation of Sinter}

Re-oxidation occurred in the furnace at quenching with water spray before dismantling the furnace for this investigation. Therefore, a laboratory scale experiment was carried out in order to estimate the influence of the re-oxidation and to know the cause of the degradation of sinter size. Re-oxidation degrees were measured under the same cooling condition with water spray by changing the initial reduction degrees.

The results obtained are as follows.

(1) There exists a proportional relationship between the initial reduction degree and the reduction degree after re-oxidation up to the reduction degree of $70 \%$, and the re-oxidation degree is 20 to $30 \%$. (Fig. 9)

(2) It is supposed that the re-oxidation by water spray occurs when the furnace temperature falls so as to the water penetrates to the lower part of the furnace.

\section{Degradation of Sinter Size}

(1) Degradation of Sinter Size in the Furnace and Its Cause

In the present investigation, as shown in Fig. 10, sinter in the shaft was found to degrade more greatly than that expected and it was wondered why sinter is so greatly degraded in a normal operation. Figures 10,11 , and 13 show the degradation indices of sinter size obtained by screening with $5 \mathrm{~mm}$ sieve opening.

The causes of the degradation have been studied by the following procedures.

Items which might cause the degradation in the furnace are,

1) Degradation of sinter with water cooling (Investigation was done after water cooling for $120 \mathrm{hr}$.)

2) Degradation during reduction

i) Degradation during operation

ii) Degradation during cooling (between blowing

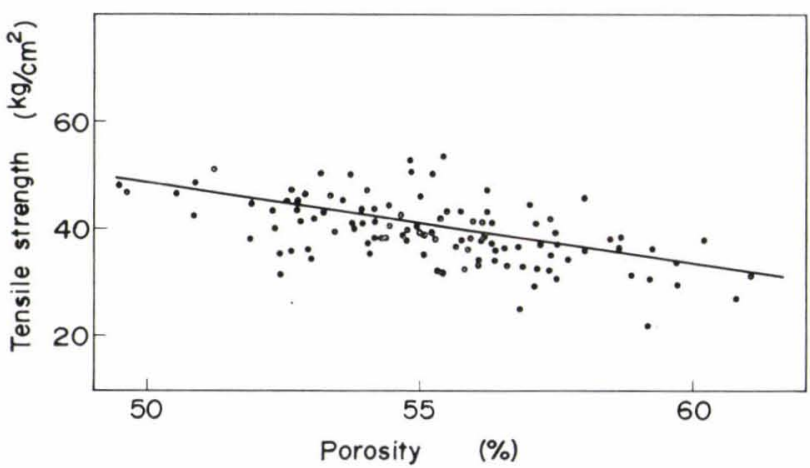

Fig. 8. Relationship between tensile strength and porosity

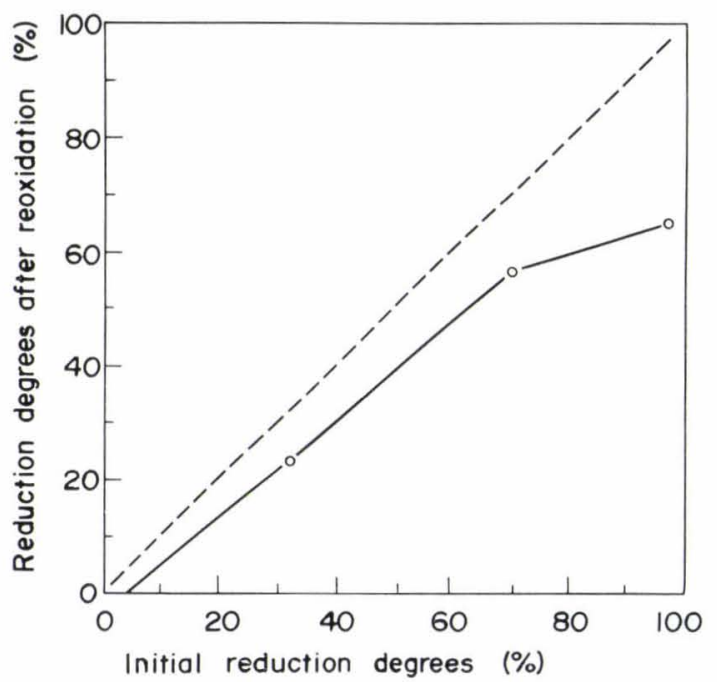

Fig. 9. Relationship between initial reduction degree and reduction degree after reoxidation

out and the time of investigation).

Those items were discussed experimentally.

(2) Experiments to Determine the Causes of Degradation

(i) Influence of Water Cooling

The results obtained by the study on the influence of water cooling are,

1) the size distribution of crude particles (under about $15 \mathrm{~mm}$ ) was affected by water cooling, but 2) the size distribution of fine particles was slightly 
affected by water cooling.

Since it was concluded from the above results that the degradation of sinter in the furnace is not likely caused by water cooling, the influence of reduction on the degradation was then studied.

(ii) Influence of Reduction on the Degradation

Items of the investigation were:

1) the influences of the reduction temperature and the gas composition

2) the influence of the reduction time

$3)$ the influence of the initial reduction degree.

(1) Influences of temperature and gas composition

Figure 11(a) shows the reduction degrees determined for $1 \mathrm{hr}$ at different temperatures and gas compositions which are corresponding to those at each height in the furnace on the basis of the gas distribution and temperature calculated from the mathematical model for the Kokura No. 2 blast furnace. The sinter having the size of 15 to $20 \mathrm{~mm}$ was used and the gas flow rate was $50 \mathrm{Nl} / \mathrm{min}$.

The velocity of degradation around $500^{\circ} \mathrm{C}$ is very high, which is evident that the amount of degradation is roughly determined by the residence time of burden materials around $500^{\circ} \mathrm{C}$ in the practical furnace as well.

It has been confirmed that the amount of degradation during the reduction process at elevating temperature and the gas composition profile are in good agreement with the values obtained by integrating the velocity of degradation shown in Fig. 11(a) with respect to the time.

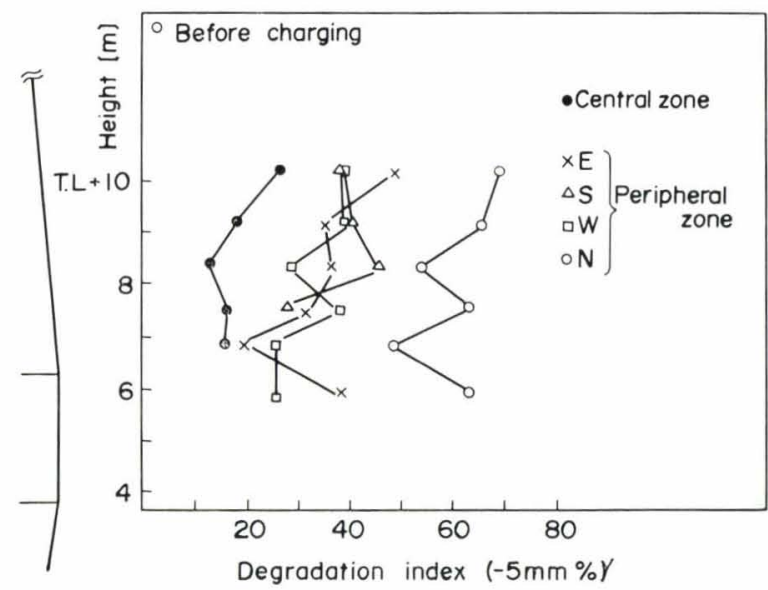

Fig. 10. Distribution of degradation index of sinter in the shaft (Kokura No. 2 B.F.)
(2) Influence of reduction time

The degradation index reveals to increase, as shown in Fig. $11(\mathrm{~b})$, roughly in proportion to the time in a reducing atmosphere of $11 \% \mathrm{CO}, 14 \% \mathrm{CO}_{2}$ and $75 \% \mathrm{~N}_{2}$ corresponding to the gas composition at the top of the furnace after blowing out. (The flow rate of gas was chosen so as to be the minimum of the apparatus, $80 \mathrm{cc} / \mathrm{min}$ in order to simulate the process of cooling of the blast furnace.)

(3) Influence of the initial reduction degree

Figure 11 (c) shows the amount of degradation when the samples are kept in a reducing atmosphere at $500^{\circ} \mathrm{C}$ for $3 \mathrm{hr}$ under the gas-flow rate of $80 \mathrm{cc} / \mathrm{min}$ after reducing to different degrees at $900^{\circ} \mathrm{C}$. The higher the initial reduction degree is, the smaller the amount of degradation is during cooling after blowing out. Degradation scarcely occurs if the reduction degree is more than $30 \%$.

From the laboratory scale experiments described above, it is concluded that the degradation of sinter for the dismantled furnace was principally caused by the reduction during operation and cooling after blowing out.

(3) Estimation of the Degradation Index and Discussion on the Causes of Degradation

Further, in order to compare the amounts of degradation during operation with those after blowing out, the degradation indices have been estimated from the results of the laboratory scale experiments, the reduction degree at blowing out and the cooling pattern on the basis of the following assumptions:

(1) The increment of the degradation index at each temperature zone during operation is additive and may be expressed as shown in Fig. 11(a).

(2) During cooling, the increment of the degradation index depends on the reduction degree at blowing out as shown in Fig. 11 (c) and is proportional to the residence time at each temperature zone as shown in Fig. 11(b). Therefore, the degradation index during cooling can be obtained by integrating the increment of the degradation index calculated for each position in the furnace from the cooling pattern.

(3) At each position of the furnace, the degradation index at blowing out (during operation) and that during cooling can be added each other.

The results calculated from the mathematical model of this blast furnace during operation were applied to the distribution of temperature in the furnace before blowing out. The results for the temperature dis-

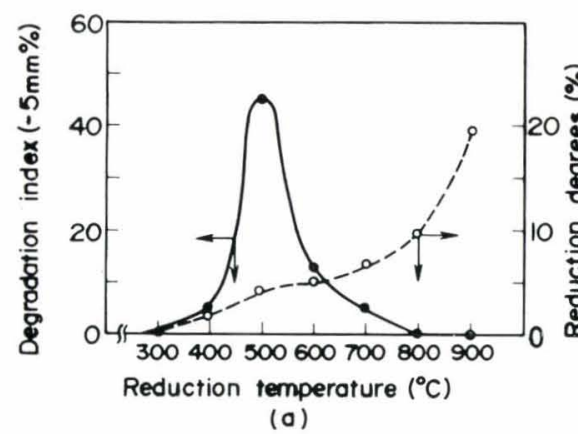

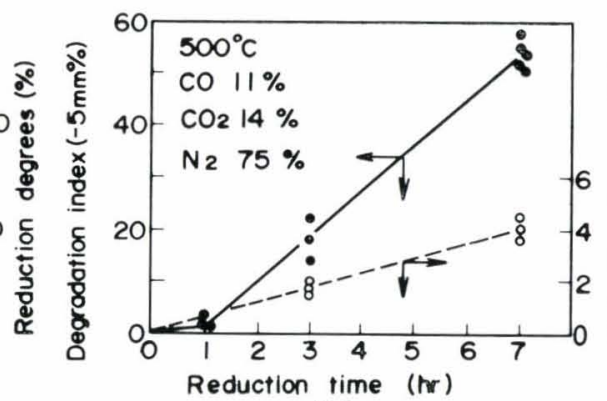

(b)

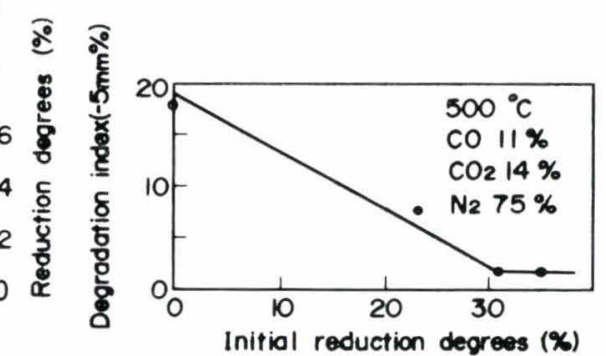

(c)

Fig. 11. Relationships between degradation index, reduction temperature, reduction time and initial reduction degree 
tribution in the furnace during cooling were obtained from the results for the initial conditions and were applied to the cooling pattern. The reduction degree at blowing out was obtained by correcting the observed one with the relationship shown in Fig. 9.

Figure 12 shows the relationships between the degradations during the periods of reduction and reoxidation and the cooling pattern after blowing out. Table 4 shows an example of comparison between the estimated degradation index and the observed one.

(1) The observed values and the estimated ones are relatively in good agreement with each other. Generally, the degradation index of sinter size in the central zone of furnace, where the reduction degree is high, is low and that in the peripheral zone where the reduction degree is low, is high.

(2) From the results of the laboratory scale experiments and the cooling pattern shown in Fig. 12, it is presumed that the degradation of sinter size in the central zone of furnace, where the reduction degree is high, is principally caused by the reduction during operation, and that in the peripheral zone where the reduction degree is low, is caused by the reduction due to a long residence time of burden materials around $500^{\circ} \mathrm{C}$ during cooling after blowing out. Judging from the gas composition at the top of the furnace after blowing out, it is presumed that the atmosphere inside the furnace was preserved to be reductive for about $40 \mathrm{hr}$ after blowing out.

(4) Estimation of the Amount of Degradation during Blowing Out

A similar phenomenon of the degradation probably occurs in a blast furnace used for the production during

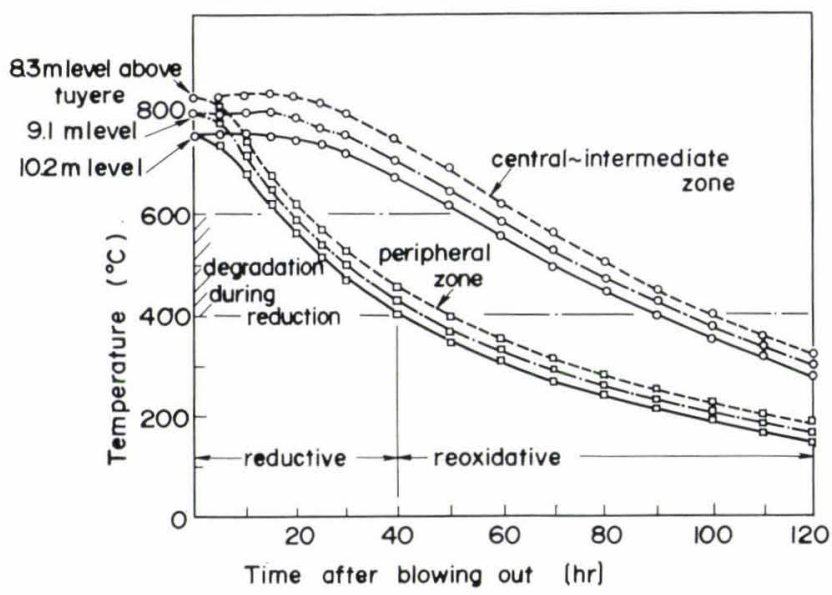

Fig. 12. Relationship between reductive or reoxidative period and cooling pattern

Table 4. Comparison of the measured degradation index with the calculated values (T.L. $+8.3 \mathrm{~m}$ level)

\begin{tabular}{l|c|c|c|}
\hline \multicolumn{1}{c|}{ Position } & $\begin{array}{c}\text { Reduction } \\
\text { degree } \\
(\%)\end{array}$ & \multicolumn{2}{|c}{$\begin{array}{c}\text { Degradation index } \\
(-5 \mathrm{~mm} \%)\end{array}$} \\
\cline { 3 - 4 } & Measured & Calculated \\
\hline Central zone & 45.8 & 14.3 & 21.4 \\
Intermediate zone & 12.8 & 22.1 & 24.6 \\
Peripheral zone & 23.5 & 41.3 & 43.4
\end{tabular}

blowing out.

Hence, taking the blast furnace A of our company as an example, the relationship between the time of blowing out and the increase in the degradation index estimated by the present method is shown in Fig. 13.

According to this,

(1) The degradation index of sinter increases with the increase of the time after blowing out, and

(2) The degradation around the middle level of the shaft is remarkable.

These results give a guide for the action before and after the blowing out.

\section{Relationship between the Deviation of Phe- nomena along the Circumferential Direction of the Furnace and the Operational Condition}

From the investigation of the inside of furnace, the properties of burden materials and their distributions are found to be deviated in the circumferential direction of the furnace. These deviations seem to be caused by the deviation of the distribution of gas flow along the circumferential direction of the furnace.

During the operation of the furnace, the diameter of the tuyere in the direction in which the protection of the steel mantle was required, was reduced, naturally showing some deviations for the distribution of gas flow and that of the descending velocity of burden in the circumferential direction of the furnace. In this furnace, as shown in Fig. 4, the diameters of tuyeres were $140 \mathrm{~mm}$ at the position of north-west, $120 \mathrm{~mm}$ at south-east, and $70 \mathrm{~mm}$ at north which was just above the tap hole and plugged at south.

\section{Deviation of the Gas Volume along the Circumferential Direction of the Furnace}

There exists a positive correlation, as shown in Fig. 14 (a), between the observed depth of raceway (distance from the tuyere nose to the shell of raceway) and the diameter of tuyere, which means that the tuyeres of different diameters produce the blasts of different energies to form raceways.

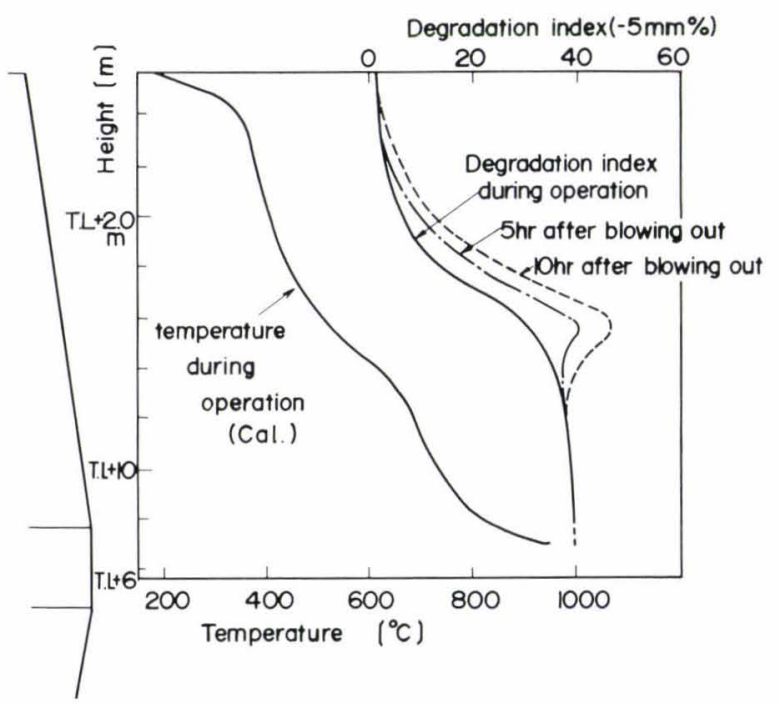

Fig. 13. Estimation of the distribution of degradation index $(-5 \mathrm{~mm} \%$ ) after blowing out (calculation) 

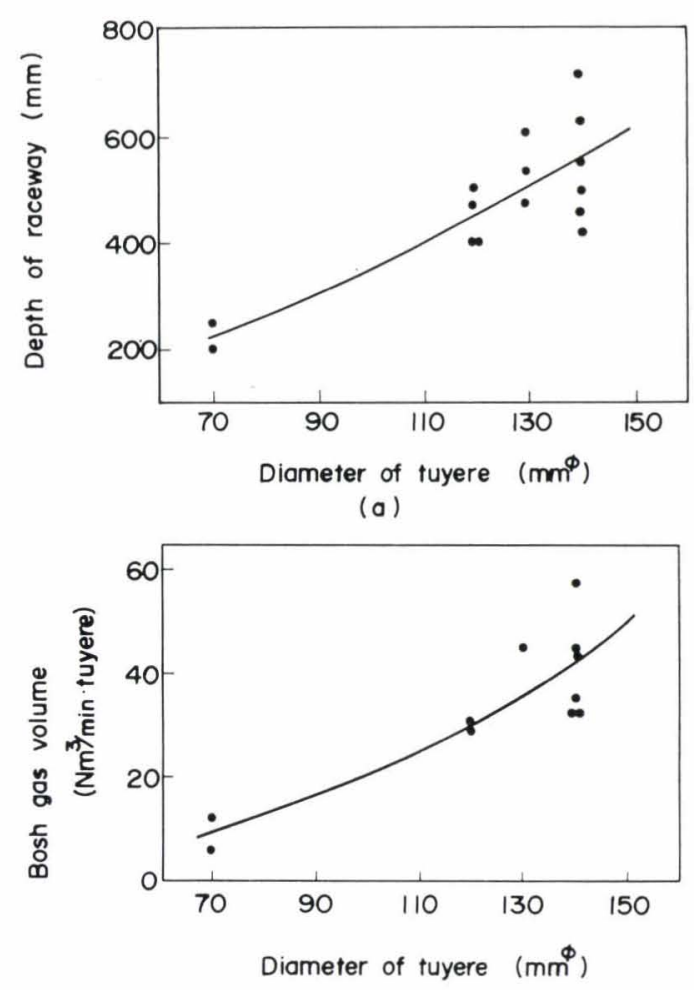

(b)

Fig. 14. Relationships between diameter of tuyere, depth of raceway and bosh gas volume

Therefore, the volume of blast at each tuyere under the blast condition at the time of blowing out shown in Table 5 was calculated and the deviation of the blast volume in the circumferential direction of the furnace was studied.

It has been confirmed by a series of experiments made by using the experimental furnace simulated to the lower part of the blast furnace at our company that there is the following relation ${ }^{8}$ between the dimensionless penetration factor $(P F)$ proposed by Wagstaff ${ }^{6}$ ) and the raceway factor $(R F)$ :

$$
P F=1.374 \times 10^{-2} \times R F+1.550
$$

where,

$$
\begin{aligned}
& P F=D_{R} / D_{T} \ldots \ldots \ldots \ldots \ldots \ldots \ldots \ldots \ldots \ldots \\
& R F=\frac{\rho_{g o} \cdot V_{g}^{2}}{g \cdot S^{2}} \cdot \frac{T \cdot P_{0}}{T_{0} \cdot P} \cdot \frac{1}{d_{s t} \cdot \rho_{s t}}
\end{aligned}
$$

$D_{R}:$ depth of raceway $(\mathrm{m})$

$D_{T}$ : diameter of tuyere $(\mathrm{m})$

$V_{g}$ : bosh gas volume $\left(\mathrm{Nm}^{3} / \mathrm{sec}\right)$

$\rho_{g o}:$ bosh gas density $\left(\mathrm{kg} / \mathrm{m}^{3}\right)$

$S:$ cross sectional area of tuyere nozzle $\left(\mathrm{m}^{2}\right)$

$T$ : theoretical flame temperature $\left({ }^{\circ} \mathrm{K}\right)$

$T_{0}$ : standard temperature $\left({ }^{\circ} \mathrm{K}\right)$

$P:$ blast pressure $\left(\mathrm{Kg} / \mathrm{m}^{2}\right)$

$P_{0}:$ standard pressure $\left(\mathrm{Kg} / \mathrm{m}^{2}\right)$

$d_{s t}$ : harmonic mean diameter of coke particles in front of tuyere $(\mathrm{m})$

$\rho_{s t}$ : apparent density of coke in front of tuyere $\left(\mathrm{kg} / \mathrm{m}^{3}\right)$

$\mathrm{g}$ : acceleration of gravity $\left(\mathrm{m} / \mathrm{sec}^{2}\right)$

Applying the known values of $D_{R}, D_{T}, d_{s t}, \rho_{s t}$ and
Table 5. The blast condition at blowing out in Kokura No. 2 B.F.

\begin{tabular}{ccccc}
$\begin{array}{c}\text { Blast } \\
\text { volume } \\
\left(\mathrm{Nm}^{3} / \mathrm{min}\right)\end{array}$ & $\begin{array}{c}\mathrm{O}_{2} \\
\text { enrichment } \\
\left(\mathrm{Nm}^{3} / \mathrm{min}\right)\end{array}$ & $\begin{array}{c}\text { Moisture } \\
\text { in blast } \\
\left(\mathrm{g} / \mathrm{Nm}^{3}\right)\end{array}$ & $\begin{array}{c}\text { Blast } \\
\text { temperature } \\
\left({ }^{\circ} \mathrm{C}\right)\end{array}$ & $\begin{array}{c}\text { Blast } \\
\text { pressure } \\
\left(\mathrm{kg} / \mathrm{cm}^{2} \mathrm{G}\right)\end{array}$ \\
\hline 800 & 0 & 21 & 1060 & 0.45
\end{tabular}

Table 6. The calculated results of bosh gas volume at tuyere

\begin{tabular}{c|ccccc}
$\begin{array}{c}\text { No. of } \\
\text { tuyere }\end{array}$ & $\begin{array}{c}\text { Diameter } \\
\text { of } \\
\text { tuyere } \\
(\mathrm{mm})\end{array}$ & $\begin{array}{c}\text { Depth } \\
\text { of } \\
\text { raceway } \\
(\mathrm{mm})\end{array}$ & $\begin{array}{c}\text { Mean } \\
\text { size of } \\
\text { coke } \\
(\mathrm{mm})\end{array}$ & $\begin{array}{c}\text { Apparent } \\
\text { density } \\
\text { of coke } \\
\left(\mathrm{g} / \mathrm{cm}^{3}\right)\end{array}$ & $\begin{array}{c}\text { Bosh gas } \\
\text { volume } \\
\text { at tuyere } \\
\left(\mathrm{Nm}^{3} / \mathrm{min}\right. \\
\text { tuyere })\end{array}$ \\
\hline 1 & 70 & 200 & 7.4 & 0.92 & 6.3 \\
2 & 140 & 430 & 10.6 & 0.92 & 32.5 \\
4 & 130 & 600 & 13.2 & 0.96 & 45.4 \\
6 & 120 & 400 & 13.4 & 0.93 & 29.2 \\
15 & 120 & 470 & 11.3 & 0.86 & 29.9 \\
16 & 140 & 620 & 11.9 & 0.82 & 45.0 \\
17 & 140 & 450 & 9.9 & 0.90 & 32.6 \\
18 & 140 & 490 & 10.5 & 0.86 & 35.5 \\
19 & 140 & 715 & 15.2 & 0.86 & 57.5 \\
21 & 140 & 550 & 12.4 & 0.91 & 43.7 \\
22 & 70 & 250 & 18.8 & 0.89 & 12.3
\end{tabular}

$S$ to Eq. (1), the bosh gas volume at each tuyere can be calculated if $T, P$, and $\rho_{q o}$ at each tuyere are constant. The calculated results are shown in Table 6 .

As is evident from Fig. 14(b) showing the calculated results, there is a positive correlation between the bosh gas volume at each tuyere and the diameter. The large tuyere installed on the north-west is pressumed to have greater gas volume than the small tuyere mounted to the south-east and that the descending velocity of burden in the north-west is higher than that in the south-east due to the deviation of gasflow.

\section{Deviation of Phenomena Taken Place in the Circum- ferential Direction of the Furnace}

As the result of the deviation of gas flow in the circumferential direction of the furnace and the deviation of the descending velocity of burden described in the previous section, the following deviations have been confirmed.

\section{Deviation of the Distribution of Softening Zones and Bed Coke}

As shown in Fig. 2, the stratified structure near by the wall continues to the level of tuyere in the cross section of south to north although it disappears at the level $2 \mathrm{~m}$ above the tuyere in the cross section of east to west. This is due to that the gas volume to heat and reduce the ore is less and the thermal level in the direction of south to north where the tuyeres are plugged or small in diameter, is lower than that in the direction of east to west where the tuyere has a larger diameter, suggesting that the position of disappearance of the softening zone depends strongly on the local condition of tuyere in the circumferential direction of the furnace.

Figure 3 shows that the melting zone of ore layer, 
i.e., the distribution of bed coke is more sufficiently developed in the north-west region than that in the south-east region.

\section{Deviation of the Distribution of the Reduction Degree of Ore}

As is indicated in Fig. 15(a) showing an example of the distribution of the reduction degree of sinter, the reduction degree in the south-east region is higher than that in the north-west region. In the south-east region, the volume of reduction gas and the descending velocity of burden are less than those in the northwest region, suggesting that the latter is more effective than the former for reduction. The reduction of ore in the furnace depends strongly on the residence time in the furnace decided by the descending velocity of burden.

\section{Deviation of the Properties of Coke}

Concerning the deviation of each property in the circumferential direction for all height of the furnace, as shown in Figs. 15(b) and (c), the hot strength of coke $\left(\mathrm{HSI}_{6}^{400}\right)$ in the south-east region is lower than that in the north-west region and the reactivity in the south-east region is higher than that in the northwest region. That is, as already mentioned in the section III.2, the deviation of the properties of coke caused by the amount of alkalis in the ash of coke, corresponding to the tendency for the distribution of the amount of alkalis, as seen in Fig. 15(d), shows a higher value in the south-east region than that in the north-west region.

The deviation of the amount of alkalis in the circumferential direction of the furnace is presumably caused by the phenomena in which alkalis having low boiling points are evaporated in the high temperature zone adjacent to the tuyere and are deposited more easily in the process of ascending in the south-east region where the gas volume is less and the temperature is lower than those in the north-west region of the furnace.

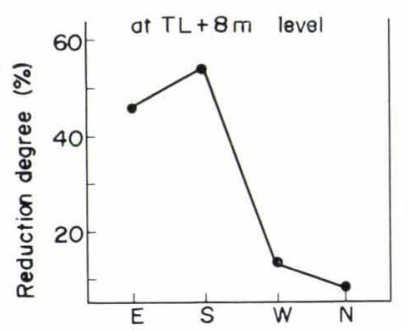

(a) Reduction degree of sinter

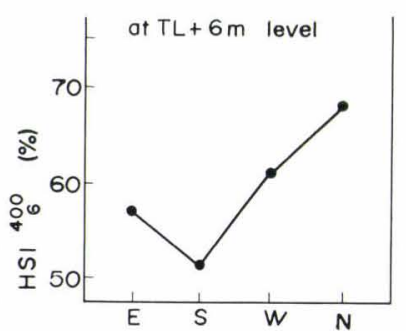

(b) Hot strength of coke

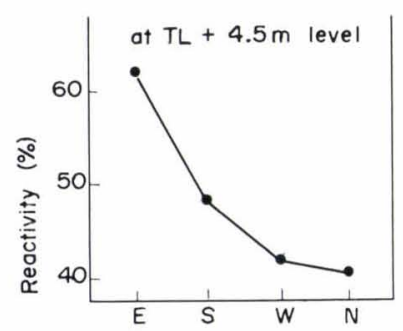

(c) Reactivity of coke

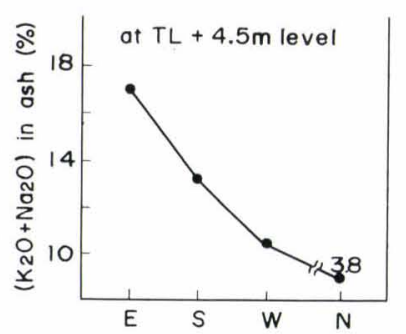

(d) Alkali oxides in ash of coke
Fig. 15. Some properties of burden materials at the peripheral direction of the furnace periphery

\section{Conclusion}

In order to scale up the furnace and to increase the productivity, it is very important from the view point of operation to control the distribution and the state of descending of burden materials in the blast furnace and the distributions and the shapes of melting zone and raceway. Therefore, an investigation of the inside of furnace to collect a comprehensive information becomes an effective method to clarify the situation and the phenomena taken place in the furnace.

By the present investigation of the dismantled $\mathrm{Ko-}$ kura No. 2 blast furnace, many valuable informations and knowledges concerning the following items have been obtained, which are very useful for the operation of blast furnaces hereafter.

1) the distributions of burden materials, melting zone and raceway in the furnace

2) the changes in the properties of coke and sinter in the furnace

3) the relationship between the operational condition and the phenomena taken plance in the furnace.

\section{REFERENCES}

1) H. Ohba, K. Hiragushi and M. Taniyama: Tetsu-toHagané, 57 (1971), S357.

2) K. Kanbara, T. Hagiwara, M. Sasaki, Y. Okuno, T. Katayama and K. Yoshizawa: Tetsu-to-Hagané, 59 (1973), A77.

3) Y. Kajikawa, N. Sumida, H. Yoshikoshi, T. Fukushima, T. Kamoshita and T. Fukuyama: Tetsu-to-Hagané, 59 (1973), A81.

4) T. Nakamura, A. Shigemi, K. Ono, A. Suzuki, H. Nakama and K. Kodama: Tetsu-to-Hagané, 61 (1975), S29.

5) W. K. Lu: "Fundamentals of Alkali Containing Compounds," Proc. McMaster Symposium on Iron- and Steelmaking No. 1, (1973).

6) R. L. Stephenson: " Effect of Alkalis on Blast Furnace Operation," Proc. McMaster Symposium on Iron- and Steelmaking No. 1, (1973).

7) J. B. Wagstaff: Proceeding AIME Blast Furnace, Coke Oven and Raw Materials Committee, (1953), 104.

8) M. Hatano, B. Hiraoka, M. Fukuda and T. Masuike: Tetsu-to-Hagané, 62 (1976), 505.

\section{Appendix}

Testing methods for the investigation of the properties of burden materials.

(1) Drum Strength DI 15 (Ref. to JIS K 2151)

Drum strength means the resistance to the abrasion of coke in a rotating drum tester.

Sampled cokes are charged into a drum tester having inner fins and the tester is revolved at a given velocity. After the revolutions, the cokes are screened and the weight fraction of $+15 \mathrm{~mm}$ cokes is defined as the $\mathrm{DI}_{15}^{n}$.

$$
n \quad \text { the number of revolutions }
$$

Sampled cokes $+50 \mathrm{~mm} \times 40 \mathrm{~kg}$

Drum tester $\quad 1500 \mathrm{~mm} \phi \times 1500 \mathrm{~mm}$ length

Inner fins $\quad 250 \mathrm{~mm} \times 1500 \mathrm{~mm}$ length $\times 6$

Revolution $\quad 15$ r.p.m. $\times 2$ min 
(2) Reactivity of Coke (Ref. to JIS K 2151)

Reactivity means the rate of solution loss reaction of coke with gaseous $\mathrm{CO}_{2}$ in a reaction tube.
Sampled coke
$10 \sim 20 \mathrm{mesh} \times 100 \mathrm{~g}$
Reaction tube $20 \mathrm{~mm} \dot{\phi} \times 600 \mathrm{~mm}$ length
Temperature $950^{\circ} \mathrm{C}$
$\mathrm{CO}_{2}$ gas velocity $50 \mathrm{ml} / \mathrm{min}$.

(3) Hot Strength $\mathrm{HSI}_{6}^{400}$

Sampled cokes are charged into a kiln which is revolved at a given velocity under the introduction of hot reaction gas.

After some revolutions of the kiln, the cokes are screened and the weight fraction of $+6 \mathrm{~mm}$ cokes is defined as the $\operatorname{HSI}_{6}^{n}$.

\begin{tabular}{ll}
\multicolumn{1}{c}{$n$} & the number of revolutions \\
Sampled cokes & $25 \sim 75 \mathrm{~mm} \times 10 \mathrm{~kg}$ \\
Kiln size & $1060 \mathrm{~mm} \phi \times 600 \mathrm{~mm}$ length \\
Reaction gas & $\mathrm{CO}_{2}=13 \sim 14 \%, \mathrm{CO}=1 \sim 2 \%$, \\
& $\mathrm{O}_{2}=2 \%, 1.2 \mathrm{Nm}^{3} / \mathrm{min}$ \\
Temperature & $1000^{\circ} \mathrm{C}$ \\
Revolution & $6.25 \mathrm{r} . \mathrm{p} . \mathrm{m} .(400$ revolutions)
\end{tabular}

(4) Microstrength MSI*

This index means the resistance to the abrasion of coke cell wall structure.

Sampled cokes and steel balls are put into a stainless tube revolving at a given velocity around the axis perpendicular to the center line of the testing tube. After a given revolutions, cokes are screened and the weight fraction of +65 mesh cokes is defined as MSI.
Sampled cokes $\quad 14 \sim 28$ mesh $\times 2 \mathrm{~g}$

Testing tube $24 \mathrm{~mm} \phi \times 300 \mathrm{~mm}$ length

Steel balls $\quad 5 / 16$ inch $\times 12$

Revolution 25 r.p.m. (800 revolutions)

(5) Tensile strength

This testing method is also known as the Brozilian Test. The cylindrical test piece, $1.5 \mathrm{~cm}$ in diameter and $0.75 \mathrm{~cm}$ in thickness, is cut out from the bulk sample of coke by using boring machine. Then, the vertical force $W$ is loaded to the test piece in the radial direction.

In this case, the tensile strength $(Q)$ is given as

$$
Q=\frac{2 W}{\pi \cdot D \cdot t} \quad\left(\mathrm{~kg} / \mathrm{cm}^{2}\right)
$$

where, $W:$ fracture strength $(\mathrm{kg})$

$D:$ diameter of test piece $(\mathrm{cm})$

$t$ : thickness of test piece $(\mathrm{cm})$.

(6) Degradation Index

The degradation index means the weight fraction of $-5 \mathrm{~mm}$ sinter after the reduction test of the sampled sinter in a reaction tube by introducing the reducing gas. (Ref. to Fig. 11)

Sampled sinter $\quad 15 \sim 20 \mathrm{~mm} \times 500 \mathrm{~g}$

Reaction tube $75 \mathrm{~mm} \phi \times 600 \mathrm{~mm}$ length

The degradation index of the sinter sampled from the inside of furnace, however, only means the weight fraction of $-5 \mathrm{~mm}$ particles without the reduction test. (Ref. to Fig. 10) 